In sweet pepper, brown lacewings prefer to oviposit on jute fibers over plants where the larvae are protected against cannibalism.

\section{Conservation of naturally occurring lacewings}

Overwintering shelters hosting diapausing adults can be used near the greenhouse to promote the early build-up of lacewing populations during spring. Such hibernation boxes (Figure 2) or 'lacewing chambers' are currently commercially

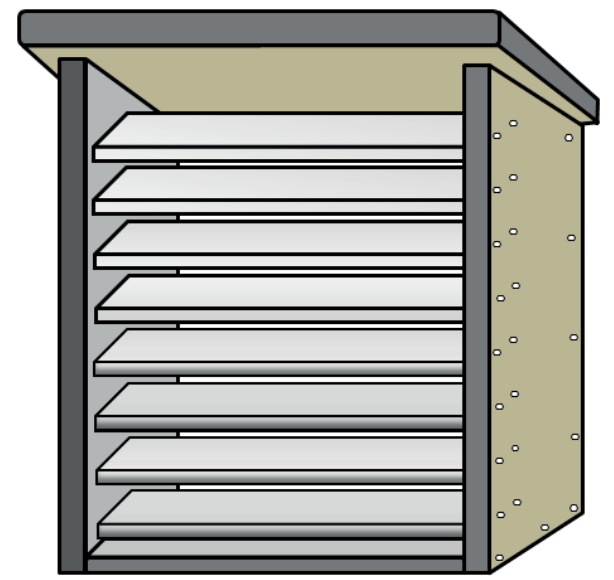

available.

Figure 2. Lacewing hibernation box.

\section{Semiochemicals}

Certain chemicals (e.g. tryptophan) or blends have been tested in the field as attractants for lacewing adults. Less is known about manipulating lacewing behaviour (mainly oviposition) by testing sex or prey-alarm pheromones. Attractants may be used in the greenhouse to lure lacewings to alternative foods and oviposition sites or to stimulate oviposition by adults.

\section{Selective use of pesticides}

Among natural enemies used in biological control, lacewings are generally considered the most resistant to pesticides. Within the context of an Integrated Pest Management (IPM) program, lacewings are compatible with selective pesticides.

\section{Food web complexities}

Intraguild predation among lacewings and other predators is not as common in the greenhouse as in the field. However, in periods of prey decline or scarcity, cannibalism among juveniles may impose a limiting factor on lacewing population growth. The provision of alternative/supplementary food for the larvae, as well as of control methods to exclude intraguild predators (e.g. ants) from the crops, are recommended to reduce such adverse effects on lacewings establishment in the greenhouse.

\section{Future directions}

Lacewings are important biological control agents currently used in augmentative releases in the greenhouse. Due to their relative resistance to pesticides and tolerance for low temperatures they are ideal for use in ornamental crops (high pesticide input crops) and in moderately heated greenhouses. Conservation research should focus on the development of tools to sustain high populations of the released lacewings, and to restrict adults inside the greenhouse (Table 1).

\begin{tabular}{|c|c|}
\hline Pros- & Conservation tool \\
\hline Generalist predators & $\begin{array}{l}\text { Food supplements, food } \\
\text { sprays, plant food }\end{array}$ \\
\hline Easy mass-rearing & $\begin{array}{l}\text { Food supplements (factitious } \\
\text { food) }\end{array}$ \\
\hline Resistance to pesticides & $\begin{array}{l}\text { Use of selective pesticides } \\
\text { (IPM programs) }\end{array}$ \\
\hline Non prey adult food & $\begin{array}{l}\text { Plant food (pollen, nectar), } \\
\text { food sprays }\end{array}$ \\
\hline $\begin{array}{l}\text { Adult attraction to protein } \\
\text { hydrolysates }\end{array}$ & $\begin{array}{l}\text { Adult attraction to } \\
\text { oviposition sites/food sources }\end{array}$ \\
\hline Plantless oviposition & $\begin{array}{l}\text { Oviposition enhancement on } \\
\text { fibres }\end{array}$ \\
\hline \multicolumn{2}{|l|}{ Cons- } \\
\hline Adult pre-oviposition flight & Adult conservation \\
\hline Larval cannibalism & $\begin{array}{l}\text { Larval conservation in the } \\
\text { absence of prey/food }\end{array}$ \\
\hline
\end{tabular}

References: Canard, M., Séméria, Y. and T. R. New 1984. Biology of Chrysopidae. Dr. W. Junk Publishers, The Hague, The Netherlands.

McEwen, P. K., New, T. R. and A.CE. Whittington 2001. Lacewings in the Crop Environment. Cambridge University Press, Cambridge, UK.

Pappas, M. L., Broufas, G. D. and D. S. Koveos 2011. Chrysopid predators and their role in biological control. Journal of Entomology, $8(3)$, pp. 301-326.

Acknowledgement: We would like to thank Prof. C.S. Henry (University of Connecticut) and Prof. Dr. P. Duelli (Swiss Federal Research Institute WSL) for reading a draft of this factsheet and for stimulating discussions. This work was supported by COST Action FA1105 "Towards a sustainable and productive EU organic greenhouse horticulture".

\section{DOI: http://dx.doi.org/10.18174/373596}

Authors: Maria L. Pappas, George D. Broufas Affiliation: Democritus University of Thrace, Greece Contact: mpappa@agro.duth.gr; gbroufas@agro.duth.gr Authors of the pictures: Figure 1: Mick Talbot material is licensed under a Creative Commons Attribution 2.0 Generic (CC BY 2.0) via Flickr. Figure 2: George Broufas 